\title{
Groundwater Management in the High Plains Aquifer in the USA: Legal Problems and Innovations
}

JoHn C. PECK

Professor of Law, University of Kansas School of Law

Lawrence, KS 66045; Special Counsel, Foulston Siefkin LLP, Overland

Park, KS 66210, USA

\section{Introduction}

\section{Description of the aquifer and the region}

The High Plains area of central USA stretches from the Rio Grand River on the south to the Canadian border on the north, and from the 'humid prairie plains' (Kromm and White, 1992, p. 1) on the east to the Rocky mountains on the west. The imprecise eastern boundary runs generally along the eastern portions of the tier of states extending from North Dakota to Texas on the south. It is generally a level, treeless, grassland surface, except along watercourses, with a windy and subhumid climate (Kromm and White, 1992, p. 1). The High Plains aquifer system, including the Ogallala and Equus Beds, is the 'largest underground reservoir in the country' (Kromm and White, 1992, p. 3; Sophocleous, 2005), contains approximately $4000 \mathrm{~km}^{3}$ of water and underlies parts of eight states. As shown in Fig. 14.1, the $570,000 \mathrm{~km}^{2}$ aquifer mostly underlies parts of three states: Nebraska has $65 \%$ of the aquifer's volume, Texas $12 \%$ and Kansas $10 \%$ (Kromm and White, 1992, p. 15). Yet, due to the varying thickness in the aquifer, only $37 \%$ of Nebraska overlies the aquifer. The saturated thickness can range from $365 \mathrm{~m}$ (Kromm and White, 1992, p. 16) to less than $1 \mathrm{~m}$ (Groundwater Atlas, 1995, p. 4). Recharge of the aquifer through precipitation is slight, ranging from a high of $15.25 \mathrm{~cm}$ annually to a low of $0.06 \mathrm{~cm}$ (Kromm and White, 1992, p. 16).

The total population in the High Plains aquifer region has hovered around 2 million since 1960, with small growth areas in some states, but with overall declines showing up in the past few years. With approximately 3.5 people/ $\mathrm{km}^{2}$, this region is very sparsely populated. The High Plains aquifer provides $30 \%$ of the groundwater used for irrigation in the USA, and approximately 


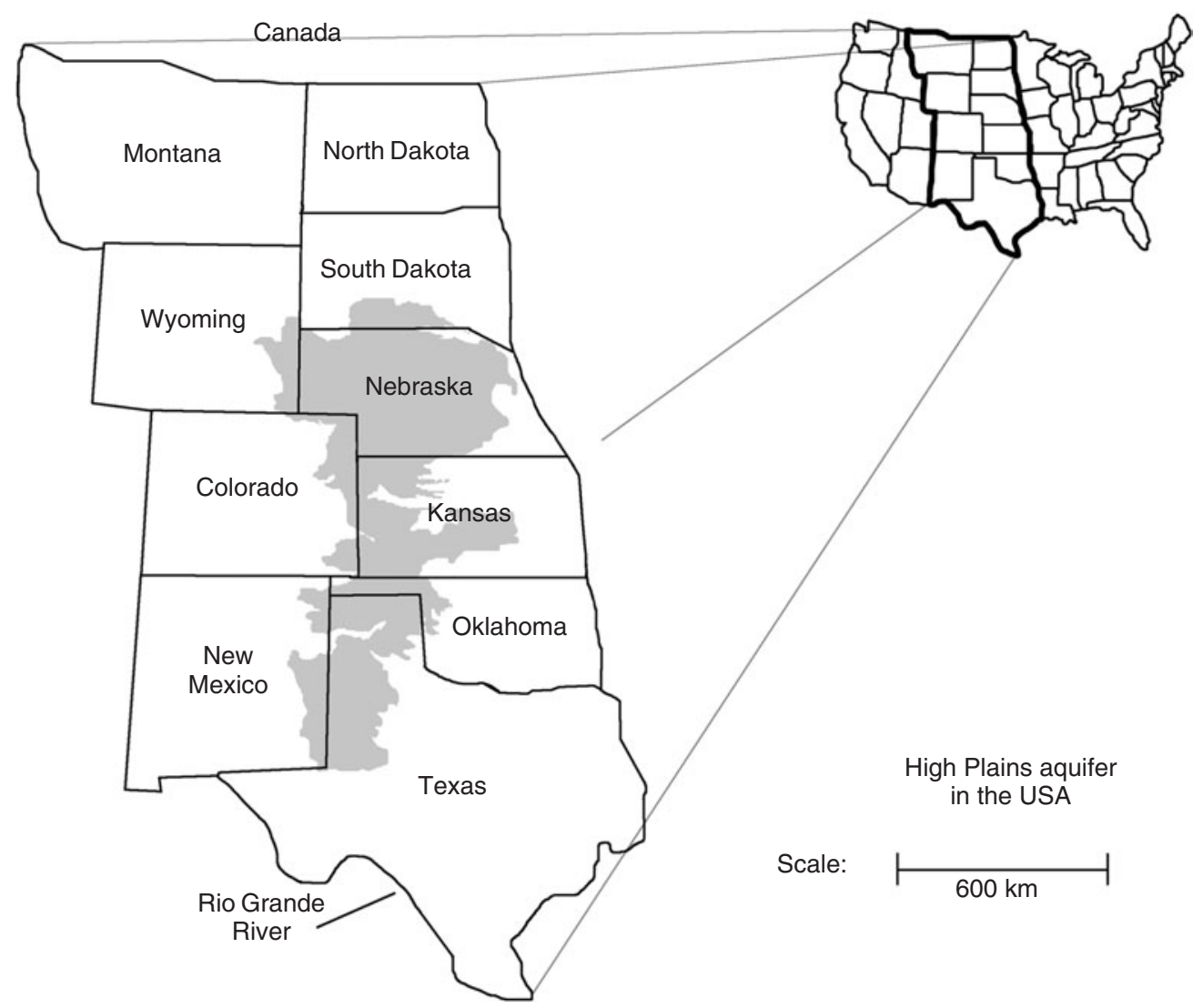

Fig. 14.1. High Plains aquifer in the USA.

$20 \%$ of the irrigated land in the USA is located in this region (Sophocleous, 2005, pp. 352-353). Agriculture dominates the economy, with virtually all land in some form of agricultural use and with the related agribusiness devoted to seed, fertilizer, pesticide, herbicide, machinery and credit (Kromm and White, 1992, pp. 17, 20). The main irrigated crops are: maize, wheat, sorghum and cotton; others include lucerne, potatoes, vegetables, soybeans and pinto beans. Centre pivot irrigation systems, typically covering circles of 52.6 ha on a square field of $64.8 \mathrm{ha}$, are common. Farm sizes typically range from 1300 to 2300 ha.

\section{Chapter overview}

This chapter concentrates on Kansas, Nebraska and Texas - the three predominantly agricultural states overlying most of the groundwater in the High Plains aquifer. American states are autonomous and able to devise their own water allocation laws, except as constrained by the US Constitutional provisions that 
protect property from being taken by the government without compensation and that delegate specific powers to the federal government, such as under the 'interstate commerce clause'. Each of the three states has a unique groundwater law, recognizes water rights as property rights and faces unique issues and problems. They have also developed innovations in groundwater management. Because relevant state boundaries are not based on the boundaries of aquifers or river basins, some interstate tensions have arisen. Moving groundwater from its source to other locations within a state or beyond a state's borders often creates disputes, leading to concern by the public, protective legislation and litigation. However, although Kansas and Nebraska are contiguous states, and Kansas, Nebraska and Texas share the High Plains aquifer, the focus of this chapter is not primarily interstate sharing or disputes over the High Plains aquifer. That issue is broached only briefly in the section on interstate conflict with the state of Kansas, which treats the Republican River Compact conflict. ${ }^{1}$

This chapter describes a range of state-level issues and responses to groundwater law. It begins with a description of groundwater law, both for the USA in general and for the three states in particular. It then follows with an account of groundwater allocation law problems faced by Kansas due to groundwater mining. The next section addresses recent groundwater issues and innovations in each state: (i) in Kansas, a water reuse project and an aquifer storage and recovery(ASR) project; (ii) in Nebraska, two types of interstate conflicts, one dealing with antiexportation statutes and the other dealing with allocation of an interstate river and the surface water-groundwater interaction with that river; and (iii) in Texas, questions about the continued efficacy of its Rule of Capture groundwater doctrine and about the advisability of moving groundwater long distances within the state. The chapter finally summarizes and draws some conclusions.

\section{Groundwater Law}

\section{American water allocation law, in general}

\section{Water vs. water rights}

In American law, water is deemed 'personal property'. Personal property includes 'goods', i.e. things that are movable. The Uniform Commercial Code covers the law of contracts for the sale of goods and would therefore cover water purchase contracts. In contrast, water rights are deemed 'real property'. A water right is a right to use a certain annual quantity of water at a certain place, diverted from a specific point of diversion at a certain rate, and in perpetuity - as long as the water right holder follows the law and the prescribed conditions of the water right. Typical real property concepts and documents apply to sales of water rights just as they apply to sales of land: the deed is the conveying instrument, the mortgage is the security document and the statute of frauds requires that contracts of sale be in writing. But water rights are not exactly like land rights: a water right is a right to use the water, not ownership of the water; some types of water rights may be lost by non-use; and state constitutions or statutes may 
declare that the state's water resource is owned by the public or dedicated to the use of the public.

\section{The law of groundwater allocation: various methods ${ }^{2}$}

Several doctrines have developed in the USA for groundwater allocation. Some states use the Rule of Capture (also known as the English Rule or Absolute Ownership Doctrine), which holds that the owner of a tract of land owns all water underneath that land and can pump water without limit, except for prohibitions on malicious or wasteful use. Similarly, the Reasonable Use Doctrine (also known as the American Rule) permits unrestricted pumping, except that the use of the water must be for a reasonable purpose and be used on the landowner's land. The Correlative Rights Doctrine holds that landowners overlying an aquifer must share the aquifer. The Prior Appropriation Doctrine applies the principle of 'first in time, first in right' to groundwater; the earlier 'senior user' may enjoin a later 'junior' right holder who impairs the 'senior' right holder's use. The Restatement of Torts $\$ 858$ rule combines elements of the doctrines of Reasonable Use and Correlative Rights.

\section{Groundwater law in the states of Kansas, Nebraska and Texas}

\section{Kansas}

The Absolute Ownership Doctrine prevailed in Kansas until 1945 when the state enacted the Kansas Water Appropriation Act (Kansas Statutes Annotated, 2005, §§82a-701, et seq.), adopting the Prior Appropriation Doctrine for groundwater. Persons wanting to divert water since 1945 have had to obtain a permit from the chief engineer of the Division of Water Resources (DWR) before diverting water. The Act allowed people who were using the water on the date the Act became effective to claim 'vested rights'. People who owned water rights by virtue of landownership alone but who were not diverting water lost their rights. From 1945 on, they had to apply for appropriation rights.

Groundwater pumping from the numerous permits granted from 1945 through the 1970s resulted in serious groundwater mining. In response the legislature enacted the Groundwater Management District (GMD) Act. Five GMDs have been established, and they have the power to enact management programmes and recommend regulations to the DWR. These regulations cover matters such as well spacing and overall aquifer withdrawal policy. For example, Southwest Kansas GMD No. 3 has a 'depletion' formula allowing a regulated lowering of the water table. The Equus Beds GMD in central Kansas has adopted 'safe yield' 3 regulations. The GMD Act provides that in cases of serious groundwater mining, the chief engineer of the DWR may establish intensive groundwater use control areas (IGUCAs) following a public hearing. It also provides that if the chief engineer establishes an IGUCA, he has extraordinary powers of regulation, including the power to reduce the annual quantity of water rights within the IGUCA.

Some quantity of groundwater in Kansas is connected hydrologically with neighbouring streams. While several states like Wyoming have water right dispute 
resolution statutes that expressly recognize this interconnection (Wyoming Statutes, 2005, §41-3-916), and some states have defined this interconnection, ${ }^{4}$ Kansas law is less clear (Peck and Nagel, 1989, pp. 199, 281-300). Yet, the chief engineer has recognized the interconnection in some situations such as in establishing IGUCAs.

\section{Nebraska ${ }^{5}$}

Nebraska uses a hybrid of the Reasonable Use Doctrine and the Correlative Rights Doctrine for groundwater rights. The right to use groundwater in Nebraska comes from ownership of the overlying land. No permit is required to drill wells except in groundwater management areas (GMAs), but owners must register them. A preference statute favours domestic use over all other uses and agricultural use over industrial or manufacturing uses. Statutes also regulate the location of wells with respect to nearby streams and other wells. ${ }^{6}$ The owner may not use more than a reasonable quantity and may have to share it with others if the groundwater supply is insufficient for all owners. While the Reasonable Use Doctrine generally prohibits the user from using water off the overlying land, Nebraska permits public water suppliers to do so, with compensation to injured overlying landowners, and also permits water use offsite for agricultural uses if it does not adversely affect other users and is deemed in public interest.

Unlike Kansas, which has five special districts devoted exclusively to groundwater management, Nebraska is divided into 23 natural resource districts (NRDs) based on river basin boundaries covering the entire state. ${ }^{7}$ Each NRD has its own priorities and programmes, covering matters such as erosion prevention, flood prevention and control, water supply, conservation of surface and groundwaters, drainage, recreation and forest management. Under the Nebraska Ground Water Management and Protection Act (Nebraska Revised Statutes, 2005, §§46-701, et seq.), groundwater management is a local rather than a state responsibility. NRDs develop management plans, which must be approved by the state director of the Department of Natural Resources. To protect the quality and quantity of water and to prevent conflicts between users of groundwater and appropriators of surface water, NRDs may establish GMAs (Nebraska Revised Statutes, 2005, §46-712) inside of which they may implement controls (Nebraska Revised Statutes, 2005, §46-739). The Act permits NRDs to regulate and control groundwater in the GMA with well spacing, pumping restrictions, rotation requirements, metering and reduction of irrigated areas.

Legislative amendments to the Act in 2004 have drawn attention to the issues of hydrologically connected surface and groundwaters (Nebraska Revised Statutes, 2005, §§46-703(2), 46-713, 46-715 through 46-718). They require evaluation of 'the expected long-term availability of hydrologically connected water supplies' (Nebraska Revised Statutes, 2005, §46-713) and create the possibility of different types of management, through the development of 'integrated management plans' (Nebraska Revised Statutes, 2005, §46-715), when the groundwater is not connected with surface water. A Nebraska Supreme Court case in 2005 recognized the right of surface water users to sue alluvial 
groundwater pumpers for damages, if the groundwater pumping causes unreasonable harm (Spear T Ranch v. Knaub, 2005).

\section{Texas}

For groundwater allocation, Texas employs the Rule of Capture, a common-law rule (judge-made, not legislated). The Rule of Capture provides that the landowners may 'take all the water they can capture under their land and do with it what they please, and they will not be liable to neighboring landowners even if in so doing they deprive their neighbors of the water's use' (Potter, 2004, p. 1). Indeed, Texas landowners own the underlying groundwater (Texas Water Code, $2005, \S 36-002)$. Texas is the only western state that follows the Rule of Capture (Potter, 2004, p. 1).

The Texas Supreme Court adopted the Rule of Capture in a 1904 case (Houston and Texas Central Railroad Company v. East, 1904), choosing to apply that rule instead of the Reasonable Use Doctrine, and in doing so cited two public policy considerations - the unknown and uncertain character of groundwater, and the fact that choosing another doctrine would generally interfere with agriculture, industry and hence the development of the state. Thus, the Texas Rule of Capture exists as a common-law rule, and court decisions have modified the Rule of Capture to prevent '(1) willful waste, (2) malicious harm to a neighbor, and (3) subsidence' (Potter, 2004, p. 9). In 1917, Texas amended its constitution to add the following Conservation Amendment:

The conservation and development of all of the natural resources of this state ... including...the conservation and development of its... water... and the preservation and conservation of all such natural resources... are each and all declared public rights and duties; and the Legislature shall pass any such laws as may be appropriate thereto.

(Texas Constitution, 2005, Art. 16, §59)

By way of this constitutional section, the legislature has the power and duty to change the Rule of Capture if necessary.

The legislature has provided for the creation of groundwater conservation districts (GCDs) to conserve, preserve and protect groundwater (Texas Water Code, 2005, §36-011) $; 87$ GCDs have been confirmed or are pending in the state, and 11 GCDs overlie portions of the Ogallala aquifer within the High Plains aquifer system. The GCD legislation, however, expressly recognizes that landowners own the groundwater (Texas Water Code, 2005, §36-002). GCDs are required to adopt management plans to address goals ${ }^{9}$ and regulate well drilling (Texas Water Code, 2005, §36-113), and are also empowered to enact and enforce rules that regulate well spacing, limit groundwater production and conserve groundwater.

Texas classifies its waters as surface water, diffused surface water and groundwater (Waters and Water Rights, 1991 and 2004 Cumulative Supplement, v. 6, p. 774). Statutes do not expressly cover the interrelationship of surface and groundwaters or provide for the conjunctive use between the two classes. Texas court decisions seem to maintain these two as distinct and separate classes 
by creating a presumption that groundwater pumped near streams causing an effect on the streams is nonetheless deemed groundwater and thus governed by the Rule of Capture (Waters and Water Rights, 1991 and 2004 Cumulative Supplement, v. 6, p. 774).

\section{Groundwater Allocation Law in Kansas: Property Rights and the Problem of Claims of 'Takings'}

\section{The legal problem: Is compensation required when the state restricts groundwater pumping?}

Like most states in western USA, Kansas follows the Prior Appropriation Doctrine for both surface and groundwaters (Waters and Water Rights, 1991 and 2004 Cumulative Supplement, v. 6; Kansas Statutes Annotated, 2005, §§82a-701, et seq.). When Kansas adopted that doctrine in 1945, replacing the Absolute Ownership Doctrine, it continued to recognize the rights then used, as 'vested rights', but eliminated unused rights without compensating the holders of those rights. Landowners not using their underlying groundwater challenged the constitutionality of the Act on the basis of an 'unconstitutional taking' for which compensation should be due from the state. The basis of such a constitutional challenge was that the US Constitution's Fifth Amendment requires the government to compensate people when it takes their property. They claimed that by eliminating their unused water rights, the state had 'taken' their water rights from them. They argued that even an unused water right was a property right. The courts, however, have upheld the Act against such challenges (Williams $v$. City of Wichita, 1962).

Another potential challenge arises when the state does not eliminate water rights entirely, but merely restricts groundwater pumping by water right holders to levels below their permitted annual quantities. Extensive regulatory reduction of pumping is arguably tantamount to a 'taking' of a property right even though the government is not technically acquiring title to the water right. While American water rights have generally been viewed as property rights, the original version of the Kansas Water Appropriation Act did not expressly define a water right as a property right. The legislature amended the Act in 1957 to define a water right to be a property right:

[A] water right is a 'real property right appurtenant to and severable from the land ... [and it] ... passes... with a conveyance of the land by deed, lease, mortgage, will, or other voluntary disposal, or by inheritance'.

(Kansas Statutes Annotated, 2005, §§82a-701 (g))

The proliferation of irrigation water rights in Kansas from the 1950s through the 1970s led to a serious groundwater mining problem. To slow pumping in the Walnut Creek Basin in west-central Kansas and thereby to protect the Cheyenne Bottoms Wildlife Preserve (an important migratory bird 
stopover point) from the pumping by the basin's more than 800 irrigation water users, the chief engineer held hearings in 1990 to establish an IGUCA. Following several weeks of hearings and testimony, the chief engineer issued an IGUCA order that established an IGUCA and recognized the interconnection of the groundwater and the Arkansas River and its tributary, the Walnut Creek. After finding that the annual basinwide 'safe yield' (sustainability ${ }^{10}$ ) was $27,753,792 \mathrm{~m}^{3}$ and that irrigators and others were pumping almost twice that quantity, the chief engineer instituted 'safe yield' in the river basin and along with it substantial reductions in irrigation pumping. The order divided the water rights into two large groups - 'senior rights' and 'junior rights' - and cut back annual quantities for both groups, but much more significantly for junior rights. The irrigators appealed the order, claiming an unconstitutional taking of property, but eventually dropped their appeal. Thus, Kansas courts have still not decided the 'takings' issue.

Whether such governmentally imposed curtailments are constitutional is an open question in Kansas. Generally in the USA, the western states by court decision are moving away from the view that a water right is an immutable property right to be treated just like a land property right. ${ }^{11}$ California, for example, has upheld the 'public trust doctrine' for water rights (National Audubon Society v. Superior Court of Alpine County, 1983), meaning that the state is viewed as holding the water resource as trustee for the people and as not having the power to grant unrestricted, unchangeable rights to its water users. The state has not only the power but also the duty to periodically review water rights in light of current conditions, not conditions existing at the time of permit issuance. States have also recognized that water use quantities may be curtailed when waste is occurring. ${ }^{12}$ Of course, the nature of the Prior Appropriation Doctrine itself requires the recognition that junior rights must be curtailed when senior rights are impaired (i.e. injured or damaged). ${ }^{13}$ But in Kansas, impairment is usually claimed in cases of alleged direct impairment (lowering of the water table or reduction of the pump rate) by the pumping of one well that adversely affects another, not by a general lowering of the water table caused by general aquifer pumping throughout the area. This view, then, might prohibit a senior well owner, whose water table is dropping, from enjoining other junior irrigators in the region where pumping generally causes areawide water table declines but does not directly impair the senior well owner's water right.

\section{The public policy issue: Should the present generation preserve groundwater for future generations?}

Aligned with the legal question of whether states like Kansas can legally restrict groundwater pumping without having to compensate the affected water right holders is the ethical and public policy question of whether Kansas should restrict pumping to preserve groundwater resources for future generations. ${ }^{14}$ Most prudent policymakers and socially conscious citizens 
would say that a society should not waste water, and Kansas has implemented measures to encourage conservation, such as requiring conservation plans for various water users (Kansas Statutes Annotated, 2005, §82a-733). It is one thing to require conservation measures, especially as express conditions on water rights permits for prospective water users; it is quite another to require reductions by current water users for the purpose of 'saving' water for future generations. Even if it were constitutional to do it without compensation, a proposition that is debatable in Kansas, the answer to the ethical question is not obvious:

The ethical question of imposing safe yield [sustainability ${ }^{15}$ ] is intriguing no matter which way one resolves the legal question - if no compensation is required, the water user suffers the immediate economic loss; if compensation is required, the taxpayer loses; in either case, forced curtailments will cause someone to suffer and sacrifice for the future.

(Peck, 2004, pp. 349, 351)

This generation's policymakers deciding the issue could consider statements of preserving water for future generations found in statutes, political platforms, the media and literature - popular, environmental and philosophic.

From the ethical arena, several rules come into play:

- $\quad$ The Golden Rule - 'Do unto others as you would have them do unto you.'

- Frankl's rule of logotherapy - 'Live as if you were living already for the second time and as if you had acted the first time as wrongly as you are about to act now!'

- Kant's categorical imperative - 'Act only on that maxim whereby thou canst at the same time will that it should become a universal law.'

- Rawls' principle - '[T]he correct principle is that which the members of any generation (and so all generations) would adopt as the one their generation is to follow and as the principle they would want preceding generations to have followed (and later generations to follow), no matter how far back (or forward) in time'.

- The simple solution to the problem of dividing a piece of pie ${ }^{16}$ (Peck, 2004, pp. 352-253).

Deciding whether to adopt strict controls on aquifer pumping to conserve water for the future is a very difficult issue. Current irrigation water users are making a 'beneficial use' of the aquifer, as defined in the current Kansas administrative regulations. Opponents to that view deem it wasteful to pump large quantities of groundwater for irrigated crops not normally grown in the otherwise dry-land wheat-farming area of western Kansas, with the resulting crops used for feeding cattle to satiate the nation and the world's hunger for beef. If Kansas were to restrict current agricultural groundwater users from pumping for the benefit of future generations, a serious disruption of the present economy of western Kansas would result. ${ }^{17}$ Moreover, it is likely that the groundwater saved and conserved for the future would eventually be pumped for municipal use, not irrigation. 


\section{Recent Issues and Innovations in Groundwater Use and Management}

\section{Kansas}

\section{Dodge City's water reuse project}

The beef cattle industry is very important to the state of Kansas as a whole ${ }^{18}$ and to Dodge City, located in south-western Kansas, in particular. Confined feed yards near Dodge City fatten cattle for slaughtering, rendering, packing and shipping, both for domestic and international purposes. The city relies on groundwater for its municipal water supply, which covers household, commercial and industrial (beef plant) uses. Faced with the cost of constructing an expensive wastewater treatment plant in the 1980s, Dodge City opted instead to pipe its municipal wastewater $17 \mathrm{~km}$ south of the city to large ponds, where the wastewater undergoes aerobic and anaerobic treatment. A farming operation then applies this wastewater for irrigating maize, milo and lucerne, thus saving the farmers the cost of buying nitrogen and other plant nutrients.

Before this water reuse project was constructed, the participating farmers had drawn freshwater from the aquifer for irrigation purposes. The city constructed the wastewater ponds near the farmers' wells and irrigated fields. The 1987 agreement between the farmers and the city provided that in exchange for the use of wastewater for a 40-year term, the farmers would lease their groundwater rights to the city, except for small amounts of water needed to dilute the treated wastewater. The city, however, did not use the groundwater under its lease from 1987 to 2004.

Recent growth in population and industry has caused the city to increase the wastewater treatment capacity at the ponds and commence use of the groundwater rights under lease for municipal purposes. For this expansion, the project participants face several legal and scientific issues and challenges to insure continued success. The change in groundwater rights is one such problem. Permission is required from the DWR to change the type of use (irrigation to municipal), place of use (farms to city) and points of diversion (old irrigation wells to new municipal wells) (Kansas Statutes Annotated, 2005, $\S 82 \mathrm{a}-708 \mathrm{~b})$. A water quality challenge is to avoid applying low-quality water that would harm the plants and pollute the groundwater. Optimizing the quality and quantity of the irrigation water insures high crop yields and highquality groundwater over time. Measures are used prior to pond treatment to remove some pollutants. Cropping choices and wastewater application schedules by the farmers are important. They must observe a fine balance: on the one hand they must maintain profitability in their farm operations, but on the other hand they must minimize pollutant migration to the groundwater by optimizing nutrient uptake and usage by the plants. As the city and its industries grow, so does the contractual obligation of the farmers to accommodate more wastewater for irrigation, requiring the farmers to acquire additional crop land. 


\section{Wichita's Equus Beds aquifer storage and recovery project}

Wichita is the largest city in Kansas and is located in the south-central part of the state, just south of the Equus Beds aquifer, the 'eastern most extension of the High Plains aquifer system' (Equus Beds Information Resource, 2005). In the 1930s, Wichita established wells in the Equus Beds and began pumping groundwater for municipal use. Running through the Equus Beds area is the Little Arkansas River, which joins the Arkansas River at Wichita.

Until the early 1990s, Wichita drew heavily from the Equus Beds aquifer. Extensive groundwater use by Wichita and irrigating farmers drew down the aquifer approximately $13 \mathrm{~m}$ in some locations, with a total loss of approximately 24.6 million cubic metres of water from aquifer storage from the time heavy pumping began in the 1940s. Irrigators with water rights junior to Wichita's water rights may have to shut down their wells if the water table keeps dropping. In addition to the lowering of the water table, the other problem in the region is a large, underground saltwater plume located north-west of the Wichita wells, migrating towards the city's well field.

Wichita is working on an ASR project to replenish the Equus Beds for the benefit of both Wichita and irrigators as well as to provide a hydraulic barrier to impede the migration of the saltwater plume moving towards the Wichita well field. The basis of the ASR project is that flood and other higher-than-normalflow water seeps down into the banks of the Little Arkansas River, is held there and can be withdrawn for recharge into the deeper Equus Beds aquifer. The plan is to refill the depleting aquifer with flood water.

A demonstration project from 1995 to 2004 showed that engineering aspects of the ASR project were feasible, but there were legal problems because of inadequate statutes and regulations. In response, the DWR worked with Wichita and promulgated a new set of regulations designed explicitly for 'aquifer storage and recovery permitting' (Kansas Administrative Regulations, 2005, $\S \S 5-12-1$, et seq.). Each applicant for an ASR project must file applications for two types of appropriation permits: (i) to divert water either directly from the river or from bank storage; and (ii) to divert water from the Equus Beds aquifer for its ultimate use. The applicant must also comply with relevant regulations of the Kansas Department of Health and Environment regarding the quality of the injected or artificially stored water.

In applying for the first permit to divert water from the river or from bank storage, the applicant must describe the volumetric area in which the water will be stored. The bottom of the basin storage area is the lowest level that has occurred within 10 years of the application; the top is the elevation representing the maximum storage potential, i.e. the pre-development water table elevation. The applicant must also include a methodology of accounting for the water stored on an annual basis to enable 'recharge credits' to be calculated. The regulation seeks an accounting system that sets up a 'water balance' for the water entering and leaving the storage area, considering recharge, groundwater inflow and outflow, evapotranspiration, groundwater pumpage of recharge credits, and all non-domestic wells in the basin storage area.

Wichita's ASR project covers four phases to be completed in 2015, with a goal of 378.5 million litres per day capacity. Phase I, scheduled for completion 
in 2007, will have a capacity of 37.85 million litres per day. At a public hearing held by the DWR in December 2004 to consider Wichita's Phase I permit applications, the public expressed concerns about the unknowns - the effect of the ASR project on groundwater quality, downstream water right holders and downstream riparian owners. The interested participants in the project (Wichita, the GMD, DWR and the public) must continually review the data and analyse the goals, objectives and performance of the project, and modify it when necessary if its twin goals of recharging the Equus Beds aquifer and halting movement of the saltwater plume for the benefit of Wichita and area irrigators are to be met.

\section{Nebraska}

Protecting the state's groundwater from interstate exportation: antiexportation statutes and the Sporhase case

American state legislatures have occasionally sought to protect natural resources from export to other states, and these restrictions have been fought in court. ${ }^{19}$ In 1967, Nebraska enacted a statute regulating the movement of groundwater out of state (Nebraska Revised Statutes, 1978, §46-613.01). It provided that groundwater could be withdrawn for use in another state if the Director of Water Resources granted a permit after finding that the withdrawal was 'reasonable,... not contrary to the conservation and use of ground water, and...not otherwise detrimental to the public welfare' (Nebraska Revised Statutes, 1978, §46-613.01). Such withdrawals were prohibited outright, however, unless the destination state granted a 'reciprocal right to withdraw and transport ground water from that state' to Nebraska (Nebraska Revised Statutes, 1978, §46-613.01).

The case of Sporhase v. Nebraska involved a farmer who owned contiguous tracts of land in Nebraska and Colorado. He irrigated both tracts from his Nebraska well without obtaining the required permit. Nebraska sought an injunction on the basis that Colorado totally banned groundwater exports and thus could not reciprocate as required by the Nebraska statute. The state was successful in the Nebraska courts. The US Supreme Court reversed the Nebraska court's decision. The Court based the decision on the Commerce Clause of the US Constitution, which gives Congress the power to regulate interstate commerce.

The case involves what is commonly called the 'negative Commerce Clause' because, while Congress has the power to enact relevant legislation dealing with the interstate movement of groundwater, it had not done so. The Court first held that water is an 'article of commerce', thus implicating the Commerce Clause. The Court then noted that the exercise of unexercised federal regulatory power does not foreclose state regulation of its water resources' (Sporhase v. Nebraska, 1982, p. 954), as long as the statute 'regulates evenhandedly to effectuate a legitimate local public interest, and its effects on interstate commerce are only incidental' (Sporhase v. Nebraska, 1982, p. 954). ${ }^{20}$ The Court also found that the first three aspects of the statute (it must be reasonable, not contrary to conservation and not detrimental to the public welfare) were 
permissible, but that the reciprocity clause was unconstitutional as being too broad a restriction:

Even though the supply of water in a particular well may be abundant, or perhaps even excessive, and even though the most beneficial use of that water might be in another State, such water may not be shipped into a neighboring State that does not permit its water to be used in Nebraska.

(Sporhase v. Nebraska, 1982, p. 958)

A reciprocity clause might be permissible only if

it could be shown that the State as a whole suffers a water shortage, that the intrastate transportation of water from areas of abundance to areas of shortage is feasible regardless of distance, and that the importation of water from adjoining States would roughly compensate for any exportation to those States.

(Sporhase v. Nebraska, 1982, p. 958)

The Court further stated that an arid state might justify a complete ban on exports by demonstrating a close relationship between the ban and conservation. The arid state of New Mexico, for example, might justify a ban if it could show that the very water it was prohibiting from export could be used to alleviate water shortages in New Mexico by piping water to those areas.

In 1984, following the Sporhase case, Nebraska amended the statute to remove the reciprocity language (Nebraska Revised Statutes, 2005, §46$613.01)$, but the amended statute retained the protection of the health, safety and welfare of its citizens. ${ }^{21}$

\section{Interstate conflict with the state of Kansas: Nebraska groundwater pumping affects the Republican River}

Disputes among American states over interstate rivers have been common. Three methods of dispute resolution have evolved: (i) a state may sue another state in the original jurisdiction of the US Supreme Court, which will apply the doctrine of Equitable Apportionment (Kansas v. Colorado, 1907); (ii) Congress may allocate the water ${ }^{22}$; and (iii) the states may settle their differences with interstate compacts, as is illustrated by the Republican River Compact entered into by Kansas, Colorado and Nebraska in 1942 (Kansas Statutes Annotated, 2005, §§82a-518).

Draining a 64,491 km² watershed, the Republican River begins in Colorado, runs eastward into Kansas, turns northward into Nebraska and then south-east running back into Kansas. Because of the interstate nature of the river and the potential for conflict, Kansas, Colorado and Nebraska signed the Compact in 1942 with a view of equitably dividing the waters of the river and its tributaries and of avoiding future conflict. The Compact provided the name and location of each basin and subbasin, defined the 'virgin annual water supply' as 'the water supply within the Basin undepleted by the activities of man' (Kansas Statutes Annotated, 2005, Art. II) and allocated to each state a portion of the virgin annual water supply. The Compact runs in perpetuity. 
In the 1990s, Kansas claimed that Nebraska was using more of its share of water by allowing unregulated pumping of alluvial groundwater. After unsuccessful facilitation talks, Kansas sued Nebraska and Colorado in the US Supreme Court in 1999. A threshold issue involved alluvial groundwater. Nebraska denied that the Compact covered groundwater pumping, in that the language of the Compact did not expressly address groundwater in its allocation scheme. The Supreme Court ruled against Nebraska on that issue, holding that '[t]he... [c]ompact restricts a compacting State's consumption of groundwater to the extent the consumption depletes stream flow in the Republican River Basin' (State of Kansas v. State of Nebraska and State of Colorado, 2002, Special Master's First Report and Case Management Order). In 2003, the states settled the other issues in the case. Some of the settlement topics included treatment of groundwater pumping (including the use of computer modelling of the groundwater system as a means of accounting for the consumption of groundwater), dispute resolution, a moratorium on the construction of new groundwater wells, formulas for determining future compact compliance, use of 5-year running averages for accounting and compliance and a framework for working together 'to improve operational efficiencies and the usable water supply in the lower Republican River basin' (Testimony of David L. Pope, 2003).

\section{Texas}

\section{Rethinking the Rule of Capture}

The century-old Texas Rule of Capture is undergoing evaluation and debate (100 Years of Rule of Capture, 2004). ${ }^{23}$ Professor Corwin Johnson said:

All that can be said in favor of the rule of capture is that it leaves the market free to allocate water to uses regarded by the market as most valuable... [but that] ... eventually its lack of restraint leads to diminishing, and eventual depletion, of the available supply of aquifers... [and that] it not only threatens the supply of water in Texas, but also deprives Texas landowners of rights they might otherwise have [because] [t] hey have no legal remedy for dewatering of their wells by others.

(Johnson, 2004, p. 11) $)^{24}$

In a paper prepared for the Texas Public Policy Foundation, water resources economic consultant Clay Landry stated:

$[T]$ he rule of capture makes it extremely difficult for landowners to conserve and manage their groundwater assets... [because] ... the only way they can protect their claim is by pumping the water... [resulting in] ... a race to the pumphouse.

(Landry, 2000, p. 1)

Support exists, however, for retaining the Rule of Capture in Texas. Those supporting the rule argue:

[T] he rule of capture in combination with regulation by local option groundwater conservation districts [GCDs] has proven to be an effective means of developing 
and managing Texas' groundwater resources... [and that] ... [a]s a practical matter, the days of operating under an unrestricted rule of capture in Texas are past... [because]... [t] he vast majority of production occurs from resources that are included within GCDs where the rule of capture is significantly limited by district rules and permitting requirements.

(Caroom and Maxwell, 2004, pp. 41, 55)

Professor Johnson recommended that the courts adopt the Restatement of Torts $\S 858$ to replace the Rule of Capture (Johnson, 2004, p. 15). Alternatively, the Texas Legislature could adopt one of the various groundwater allocation doctrines used by other states, ${ }^{25}$ or 'ignore the rule of capture, and continue on its present course of addressing directly groundwater problems' (Johnson, 2004, p. 16). While adopting the Prior Appropriation Doctrine 'would be helpful' because of the quantification of the rights, integration with surface water and preservation of historic use, that doctrine too would have disadvantages, as noted elsewhere in this chapter (Johnson, 2004, pp. 16-17). Water resources economist Landry concluded in his paper that because '[s]trong markets make for good markets' (Landry, 2000, p. 3), '[p] roperty rights and water markets offer the best hope among all other options for efficiently and equitably allocating this precious resource to its most highly valued uses' (Landry, 2000, p. 8). Supporters of the Rule of Capture argue that refinement, not replacement, would be preferable.

\section{Moving Ogallala aquifer groundwater to other uses and places in Texas}

Nebraska's attempt to prevent the interstate movement of water has been discussed earlier. However, some states place limits on the intrastate movement of water. The Kansas Water Transfer Act, for example, regulates water diversions exceeding 2.36 million cubic metres per year transported $56 \mathrm{~km}$ or more, with special permitting requirements (Kansas Statutes Annotated, 2005, $\S \S 82 \mathrm{a}-1501$, et seq.).

In contrast, the Rule of Capture in Texas permits landowners to pump water and use it on or off the land overlying the aquifer. Diversions of the Ogallala aquifer groundwater already exist in Texas, and more are planned. For example, the Canadian River Municipal Water Authority (CRMWA), which supplies water to almost 500,000 people in 11 cities, draws water from Lake Meridith and Ogallala wells in the Texas Panhandle. The CRMWA has obtained permits for 49.32 million cubic metres of water per year from the Panhandle Groundwater Conservation District \#3. The City of Amarillo has also purchased water rights for 177,840 ha in Roberts County (Water Ranching, 2002).

The Mesa Water Project (MWP), a large project proposed in 1999, would pump and move 246.6 million cubic metres of Ogallala aquifer water per year to municipalities in the state. The MWP involves 200 landowners in the Texas Panhandle and initially includes approximately 988,000 ha in Roberts County, one of four counties involved in the project (Mesa Water, 2005). These four counties cover 6,125,000 ha, with 247,000 ha now in irrigation. The project sponsors hope to help meet Texas' water needs over the next 125-200 years by constructing an extensive pipeline from the source wells 
to various reservoirs associated with the Brazos River and using the river itself as a conduit, thus making conjunctive use of surface and groundwaters. Ultimate water purchasers include the Dallas-Fort Worth metropolitan area, San Antonio and other cities.

Such large diversions of groundwater over long distances in Texas are not without controversy. The concerns involve matters such as the privatization of water supplies (Knickerbocker, 2002); claims that the withdrawals may greatly exceed recharge (Eaton and Caplan, 2003), leaving no water for the children and grandchildren of the local people (McKenzie, 2004) and the otherwise adverse effects on rural communities (Water and the Future of Rural Texas, 2001); the failure of these water marketing projects to take third party effects into account (Water and the Future of Rural Texas, 2001); the lack of a state groundwater policy (Water and the Future of Rural Texas, 2001) and water quality, wildlife and environmental issues when fresh groundwater is mixed with salty river water (Ostdick, 2004).

\section{Conclusion}

\section{Introduction}

The High Plains aquifer region is an agricultural area of modest precipitation, sparse population, relatively large farms and abundant but declining groundwater resources. Ironically, while the landforms, land use, demography and water resources are fairly uniform across the entire region, what varies among the states are the laws and the legal institutions regulating the water resources. The question is whether the ideas presented in this chapter involving American water law have relevance and applicability in other regions of the world.

\section{Water rights law and water rights doctrines}

Each legal doctrine involving groundwater allocation and use discussed in this chapter has merits and demerits. The Rule of Capture applied in Texas, giving landowners ownership of underlying groundwater, provides great freedom of use by the landowner, but gives little protection against impairment by neighbours and little control by the state over the declining water table. The same holds true with the doctrines of Reasonable Use and Correlative Rights employed by Nebraska. With its requirements of permits prior to use, Kansas' Prior Appropriation Doctrine applied to groundwater provides a greater level of state control and protection of the water rights from other users. The doctrine's disadvantages are the lack of freedom of groundwater use by landowners and a heavy requirement of state resources (money and personnel) necessary to administer the complex system of water rights. However, once water rights are obtained under the various doctrines, all three states recognize them as property rights protected against government takings without compensation by the US Constitution's Fifth Amendment. 
While the three states apply different allocation doctrines to its groundwater resources, a common and important element is that in each state the legal doctrine was applied early on, and it developed along with the growth of the state's population and water use. Even in Kansas, which changed from the Rule of Capture to the Prior Appropriation Doctrine in 1945, the predominant period of groundwater development occurred after 1945. Thus, there has been no need to superimpose a doctrine on a state having no prior existing water allocation law.

If a country has a problem of extensive exploitation of groundwater, it may benefit from having laws in place to administer, control and limit groundwater pumpage (Singh, 2002). ${ }^{26}$ Water allocation law could help if a country has the power to gain control over the groundwater resource and to provide some system of controlling further water use. However, having groundwater management laws in place does not necessarily insure groundwater conservation or prevent groundwater mining, as is shown by the declining groundwater problems in the High Plains aquifer states (Peck, 2003). ${ }^{27}$ Enacting groundwater management laws prior to the onset of intensive groundwater exploitation is preferable to waiting until exploitation occurs, but many countries in the world already find themselves dealing with aquifers that have declining yields, water quality or both.

Choosing a water allocation method is difficult, and the methods used in America are, of course, not the only choices. Some of the selection factors to be considered by a country include the type of legal doctrine already in place, if any, including constitutional protection of property against government takings without compensation; the extent to which groundwater resources are already being overused and the current rate of growth of groundwater use; the density of population and water wells; the strength and viability of the judiciary, administrative agency system and legal system in general to resolve water disputes expeditiously; and the availability of public funds and hydrologic and other scientific and legal expertise and data available to administer the system. ${ }^{28} \mathrm{~A}$ country having areas with large numbers of groundwater irrigation users per unit area might find the costs of administration of the Prior Appropriation Doctrine prohibitive. Moreover, superimposition of strict regulations might result in serious unrest or even revolt among water users. It might be preferable to have a system in which water rights are clearly defined, but little or no continuous administration is involved. For example, an alternative to the US doctrines might involve a hybrid system that would establish new rights and recognize existing ones, but having them last for a term of approximately 20 years as opposed to having them last in perpetuity. ${ }^{29}$ Water could be reallocated at the end of the term. The rights could be freely transferrable, and disputes could be resolved by arbitration or other alternative forms of resolution.

\section{Water conservation, water reuse, water recharge and recovery}

This chapter has described various private projects and government actions that attempt to conserve groundwater in central USA. While technological advances 
continue to improve efficiencies in irrigation and other water uses, legal and economic problems can arise when the government imposes conservation on existing water users. In the USA, change has been slow but sure: as technology improves, the law has slowly increased its involvement in overall management of groundwater. Claims of compensation for 'taking' of property when the state reduces water right quantities are weaker when the state gradually puts conservation measures in place. But the threat or perceived inevitability of such regulation combined with the need for additional water can produce innovation in conserving existing supplies and in acquiring new ones, as demonstrated by Dodge City's reuse project and Wichita's recharge and recovery project.

\section{Laws limiting the movement of water across political boundaries}

A country with its internal state boundaries overlying groundwater aquifers may face situations similar to that of Nebraska in the Sporhase case. The Supreme Court's decision resulted in a limitation on state power to prevent the movement of groundwater to points outside its state boundaries. From a policy standpoint, this decision seems to strike a suitable balance between the needs of the state in protecting the health and welfare of its citizens in times of crises and the needs of a free flow of commerce. Other countries may have to make this policy decision based on other principles and considerations, but it would seem that the Sporhase balance might be universally relevant, at least in considering these two factors.

The proposal of the MWP to make large intrastate diversions of Texas groundwater presents different legal and policy issues than those of interstate diversions. Even intrastate water diversions cause public concern about the disruption of the economies of the places of origin as well as environmental, human displacement and other costs. If a state government has power over its water resources, it can make necessary policy judgements about the costs and benefits to the exporting and importing areas in the state, and can take into account relevant externalities. If a government employs the Rule of Capture, however, it has tacitly left such decisions in the hands of private enterprise.

\section{Conflict resolution between political entities}

It may be preferable for countries to have conflict resolution procedures in place before disputes arise, whether the conflicts are among individual water users, states within countries or neighbouring countries. The water law allocation doctrines applied by the three American states are mainly applicable to individual water users. Of the three methods of interstate water conflict resolution in the USA mentioned earlier, the interstate compact is theoretically preferable, as the states have agreed to the allocation in advance. Compacts sometimes come about only after one state has had to resort to a lawsuit seeking equitable apportionment in the Supreme Court, and recent litigation indicates that having a compact does not insure against further disputes. Having two states to 
recognize, discuss, negotiate and resolve their disputes by compact, however, seems preferable to the uncertainty of equitable apportionment decided by the Supreme Court. Interstate water dispute resolution involves a complexity and level of detail that makes it generally unsuitable for Congressional allocation.

\section{Notes}

1 To date, interstate water compacts have involved primarily rivers and only tangentially groundwater. Litigation on one such compact is discussed in the section on interstate conflict with the state of Kansas. However, a model interstate compact specifically involving groundwater is being discussed (The Utton Center, 2004), and Oklahoma legislation in 2001 proposed a multistate groundwater compact (The Bimonthly Newsletter, 2001).

2 For surface water allocation, the USA is divided into two regions and two doctrines. In the eastern states, those states lying east of the High Plains region, precipitation is abundant. These states use the 'Riparian Doctrine'. By virtue of owning land adjacent to a river, riparian landowners have the right to use a reasonable amount of water on their riparian tracts, but their rights are shared with other owners. They neither gain their rights by using the water nor lose them by ceasing to use the water. Courts settle disputes.

In the west, the 'Prior Appropriation Doctrine' holds that 'first in time is first in $r_{i g h t}$ '. The first person to use water along a stream gains the 'senior right' to a reasonable quantity for that type of use. Each right that follows is 'junior' to the senior right, but senior to those that follow still later. In times of water shortage, junior rights may be shut down in favour of more senior rights. Most western states now have elaborate administrative systems requiring permits prior to diversion. Water use is not restricted to riparian land. Rights not used are lost by abandonment. Either courts or administrative agencies settle disputes.

3 Apparently, terms such as 'safe yield' and 'aquifer overdraft' have fallen out of favour with groundwater hydrologists. 'Sustainable use' has replaced 'safe yield', and 'intensive groundwater exploitation' has replaced 'aquifer overdraft'. Nevertheless, this chapter uses the term 'safe yield' throughout, because Kansas regulations continue to use the term. Kansas Administrative Regulations §5-1-1 (mmm) defines 'safe yield' as 'the long-term sustainable yield of the source of supply, including hydraulically connected surface or groundwaters.'

4 For example, the final report of the special master in Nebraska v. Wyoming (No. 108, Original, US Supreme Court) contains this statement: 'The settlement negotiations, therefore, specifically addressed that groundwater pumping concern, and the parties agreed on a definition of a 'hydrologically connected groundwater well' as a well 'so located and constructed that if water were intentionally withdrawn continuously for 40 years, the cumulative stream depletion would be greater than or equal to $28 \%$ of the total groundwater withdrawn by that well.' NPDC Charter, Ex. 4, para. III.D.2.b' (Nebraska v. Wyoming, 2001, p. 31).

5 Professor Norm Thorson and others have provided summaries of Nebraska water law (Thorson, 1991, pp. 494-496; Nebraska Water Policy Task Force, 2004).

6 The Nebraska legislature has expressly found that pumping water for irrigation from wells located within $50 \mathrm{ft}$ of the bank of a stream may have a direct effect on the stream (Nebraska Revised Statutes, 2005, §46-636), requiring a permit in such cases (with some exceptions) (Nebraska Revised Statutes, 2005, §46-637). Another legislative section prohibits the drilling of irrigation wells within $600 \mathrm{ft}$ of a registered irrigation well (Nebraska Revised Statutes, 2005, §46-609). 
7 The Nebraska Association of Resource Districts is the trade association for the NRDs (Nebraska Association of Resource Districts, 2005).

8 The Edwards aquifer supplying San Antonio with municipal water supply is not part of the High Plains aquifer. The legislature has treated the Edwards aquifer differently by empowering the Edwards Aquifer Authority to regulate and restrict Edwards aquifer use (Waters and Water Rights, 1991 and 2004 Cumulative Supplement, v. 6, pp. 787-792).

9 These goals include the following: (i) providing the most efficient use of groundwater; (ii) controlling and preventing waste of groundwater; (iii) controlling and preventing subsidence; (iv) addressing conjunctive surface water management issues; (v) addressing natural resource issues; (vi) addressing drought conditions and (vii) addressing conservation (Texas Water Code, 2005, §36-1071).

10 See footnote 3 .

11 The classic statement of this trend appears in a California case: 'All things must end, even in the field of water law. It is time to recognize that this law is in flux and that its evolution has passed beyond traditional concepts of vested and immutable rights' (Imperial Irrigation District v. Water Resources Board (1990), pp. 250, 267). To some extent, Texas is an exception. In 1999, the Texas Supreme Court refused to abandon the Rule of Capture in favour of the Reasonable Use Doctrine (Sipriano v. Great Springs Waters of America, Incorporated. 1999) discussed earlier.

12 In the Imperial Irrigation District case, the California court did not define waste, but concluded that 'wasteful practises' included 'canal spills, excess tailwater (the water running off the "tail" of a farm as the result of excess water being introduced at the "head" of the system), and ...canal seepage' (Imperial Irrigation District V. Water Resources Board, 1990, p. 258). In Kansas, DWR regulations define 'waste of water' as 'any act or omission that causes any of the following: (i) The diversion or withdrawal of water from a source of supply that is not used or reapplied to a beneficial use on or in connection with the place of use authorized...(ii) the unreasonable deterioration of the quality of water...thereby causing impairment...(iii) the escaping and draining of water intended for irrigation use... or (iv) the application of water... in excess of the needs for this use' (Kansas Administrative Regulations, 2005, §5-1-1 (cccc)). GMD regulations prohibit waste of water (Kansas Administrative Regulations, 2005, §§5-21-2 and 5-22-3).

13 Kansas statutes do not expressly define the term 'impair', but K.S.A. §82a-711 states that impairment shall include the unreasonable... lowering of the static water level... beyond a reasonable economic limit.' A 1973 Kansas district court case held that impairment had occurred when 'plaintiff's authorized diversion rate is decreased by at least $20 \%$ in addition to the rate reduction caused by the pumping of plaintiff's irrigation well' (File v. Solomon Valley Feedlot, Incorporated, 1973, para. 5).

14 Other authors raise the same issue (Llamas, 2004, p. 9).

15 For the use of the term 'safe yield', see footnote 3.

16 The example of dividing a piece of pie requires one child to cut the larger piece into two parts and then permits the other child to pick which piece he or she wants.

17 Llamas presents a similar view: 'Fossil groundwater has no intrinsic value if left in the ground except as a potential resource for future generations, but are such future generations going to need it more than present ones?' (Llamas, 2004, p. 9)

18 'Kansas ranked second nationally with 6.65 million cattle on ranches and feed yards as of January 1, 2004. ${ }^{* * *}$ Cattle represented $61 \%$ of the 2002 agricultural cash receipts. ${ }^{* * *}$ Kansas ranks second in commercial cattle processed with 8.9 million head in $2003 \ldots$... second in value of live animals and meat exported to other countries at $\$ 822.2$ million in $2001 \ldots$ second in fed cattle marketed with 5.5 million in 2003 ... [which] represents $23.2 \%$ of all cattle fed in the USA' (Economic Impact of the Kansas Livestock Industry, 2005). 
19 Oklahoma, for example, once sought to prohibit interstate transfer of minnows seined from waters of the state (Hughes v. Oklahoma, 1979). Other examples include natural gas (West v. Kansas Natural Gas Company, 1911; Pennsylvania v. West Virginia, 1923); game birds (Geer v. Connecticut, 1896); river water (Hudson County Water Company v. McCarter, 1908) and groundwater (City of Altus v. Carr, 1966).

20 Citing Pike v. Bruce Church, Incorporated, 1970.

21 The Nebraska Supreme Court upheld the constitutionality of the new section (Ponderosa Ridge LLC v. Banner County, 1996). Similarly, Kansas amended Kan. Stat. Ann. §82a-726 in 1984 to remove a comparable reciprocity provision and to protect the 'public health and safety' of its citizens.

22 In Arizona v. California, 1963, the US Supreme Court held that the Boulder Canyon Project Act 1928, enacted by the US Congress, represented a comprehensive scheme of apportioning waters of the Colorado River.

23 The Texas Water Development Board held a symposium on the subject in June 2004.

24 The late Professor Corwin Johnson taught at the University of Texas School of Law and was a leading authority on Texas water law.

25 See page 99, above.

26 The following is a contrasting position: 'Many policy researchers, including the IWMI-Tata researchers... believe the case for direct regulation hopeless in south Asian settings, not because it is unnecessary or undesirable but on the grounds of administrative feasibility and costs.' The authors, however, point out that 'China's experience with direct management (including well and withdrawal permits) ... has at least shown some positive signs' (Shah et al., 2004, p. 3456).

27 That article came out of a paper delivered at the World Water Council 3rd World Water Forum in Kyoto, Japan, in March 2002.

28 In my talk on groundwater doctrines at the 3rd World Water Forum, I described the Cheyenne Bottoms dispute, which involved 800 irrigators in a dispute with 15 lawyers taking over 2 years to resolve. See pages 302-303 on the necessity of compensation. Dr Singh responded to that in contrast, the comparable situation in India would involve 8000 irrigators in an even smaller geographical area, with perhaps only one or two lawyers and requiring more than 20 years for the judicial system to resolve the issue. In 'irrigation institutions', the authors state that India has '20 odd million pump owners, a number that is growing at the rate of 0.8-1 million per year' (Shah et al., 2002, p. 3456).

29 South Dakota, for example, provides that permits for works to withdraw water from the Madison formation in certain counties are limited to 20 years, unless the Water Management Board determines that there would be no adverse effects on other Madison formation users (South Dakota Codified Laws, 2005, §46-2A-20).

\section{References}

Arizona v. California, 373 U.S. 546, 83 S.Ct. 1468, 10 L.Ed.2d 542 (1963).

Boulder Canyon Project Act of December 21, 1928, 45 Stat. 1057.

Caroom, D.G. and Maxwell, S.M. (2004) The Rule of Capture - If It Ain't Broke...., 100 Years of the Rule of Capture: From East to Groundwater Management. Available at: http://www.twdb.state.tx.us/publications/
reports/GroundWaterReports/GWReports/ Report\%20361/4\%20CH\%20Caroom.pdf.

City of Altus v. Carr, 255 F. Supp. 828 (W.D. Texas, summarily aff'd, 385 U.S. 35 (1966)).

Eaton, J.M. and Caplan, R. (2003) Water for People and Nature: The Story of Corporate Water Privatization, Available at: http:// www.thealliancefordemocracy.org/pdf/ wpn01.pdf. 
Economic Impact of the Kansas Livestock Industry (2005), Kansas LivestockAssociation. Available at: http://www.kla.org/economics. htm

Equus Beds Information Resource, A partnership of the Kansas Department of Health and Environment, GIS Policy Board, Data Access and Support Center and Information Network of Kansas, Inc. (2005) Available at: http:// www.equusinfo.org/tech_narrative.shtml.

File v. Solomon Valley Feedlot, Incorporated, No. 8831, para. 5 (District Court, Mitchell County, Kansas, 1973).

Geer v. Connecticut, 161 U.S. 519, 16 S.Ct. 600, 40 L.Ed. 793 (1896).

Groundwater Atlas of the United States. (1995) High Plains Aquifer, U.S. Geological Survey. Available at: http://capp.water.usgs.gov/gwa/ ch_c/C-text5.html.

Houston and Texas Central Railroad Company v. East, 98 Tex. 146, 81 S.W. 279 (1904).

Hudson County Water Company v. McCarter, 209 U.S. 349, 28 S.Ct. 529, 52 L.Ed. 828 (1908).

Hughes v. Oklahoma, 441 U.S. 322, 99 S.Ct. 1727, 60 L.Ed.2d 250 (1979).

Imperial Irrigation District v. Water Resources Board, 225 Cal.App.3d 548, 275 Cal. Rptr. 250 (Cal. App. 4 Dist.) (1990).

Johnson, C.W. (2004) What Should Texas Do About the Rule of Capture? 100 Years of Rule of Capture: From East to Groundwater Management, Texas Water Development Board, Report 361. Available at: http:// www.twdb.state.tx.us/publications/ reports/GroundWaterReports/GWReports/ Report\%20361/2\%20CH\%20Johnson.pdf.

Kansas Administrative Regulations (2005) Office of Revisor of Statutes of Kansas. Topeka, Kansas.

Kansas Statutes Annotated (2005) Office of Revisor of Statutes of Kansas, Topeka, Kansas. Kansas Legislature 2005-2006. Available at: http://www.kslegislature.org/legsrv-statutes/ index.do.

Kansas v. Colorado, 206 U.S. 46, 27 S.Ct. 655, 51 L.Ed. 956 (1907).

Knickerbocker, B. (2002) Privatizing water: a glass half empty? Christian Science Monitor 24 October. p. 1. Available at: http://www. csmonitor.com/2002/1024/p01s02-usec. htm.
Kromm, D.E. and White, S.E. (1992) Groundwater Exploitation in the High Plains, University Press of Kansas, Lawrence, Kansas.

Landry, C.J. (2000) A Free Market Solution to Groundwater Allocation in Texas: A Critical Assessment of the House Natural Resources Committee Interim Report on Groundwater. Available at: http://www.texaspolicy.com/ pdf/2000-12-01-environ-water.pdf.

Llamas R. (2004) Water and Ethics: Use of Groundwater, UNESCOInternational Hydrological Programme, World Commission on the Ethics of Scientific Knowledge and Technology. Available at: http://racefyn. insde.es/academicos/descargas/Llamas/ UWEG136322e.pdf

Llamas, R. and Custodio, E. (2002) Intensively exploited aquifers: Main concepts, relevant facts and some suggestions, UNESCO, IHPVI, Series on Groundwater No. 4, UNESCO, IAH, Marcelino Botin Foundation. Available at: http://www.iah.org/News/2002/inexaqcd. pdf.

McKenzie, W. (2004) Forget gasoline prices, Texans need to talk water, The Dallas Morning News. Available at: http://www.mesawater. com/ReferenceResources/ref_materials_ detail.asp?id=20.

Mesa Water (2005) Working to improve the future of Texas water. Available at: http:// www.mesawater.com/default2.asp.

National Audubon Society v. Superior Court of Alpine County, 33 Cal.3d 419, 658 P.2d 709, 189 Cal.Rptr. 346 (1983).

Nebraska Association of Resource Districts (2005) Available at: http://www.nrdnet.org/index.htm.

Nebraska Revised Statutes (1978) Nebraska Legislature. Available at: http://srvwww. unicam.state.ne.us/Laws2005.html.

Nebraska Revised Statutes (2005) Nebraska Legislature. Available at: http://srvwww. unicam.state.ne.us/Laws2005.html.

Nebraska v. Wyoming (No. 108, Original, U.S. Supreme Court), Final Report of the Special Master (2001), p. 31. Available at : http:// www.dnr.state.ne.us/PDF/FinalReport1.pdf.

Nebraska Water Policy Task Force (2004) Nebraska Department of Natural Resources. Available at: http://www.dnr.state.ne.us/ watertaskforce/docs/TFResourcematerials. html. 
100 Years of Rule of Capture: From East to Groundwater Management (2004) Texas Water Development Board, Report 361. Available at: http://www.twdb.state.tx.us/publications/ reports/GroundWaterReports/GWReports/ Report\%20361/361_ROCindex.htm.

Ostdick, J.H. (2004) A Natural River, Texas Parks and Wildlife. Available at: http://www. tpwmagazine.com/archive/2004/jul/ed_7/.

Peck, J.C. (2003) Property rights in groundwater - some lessons from the Kansas experience, Kansas Journal of Law and Public Policy, XII, p. 493. Available at: http://64.233.167.104/ search?q=cache:kTtQD9ipNPEJ:www.ku.edu/ $\sim$ kulaw/jrnl/v12n3/peck.pdf+\%E2\%80\%9C Property+Rights+in+Groundwater $\%$ E2\%80 $\% 93$ Some+Lessons+from+the+Kansas+Exp erience\&hl=en; http://www.ku.edu/ kulaw/ jrnl/v12n3/peck.pdf.

Peck, J.C. (2004) Protecting the Ogallala aquifer in Kansas from depletion: the teaching perspective, Journal of Land, Resources, and Environmental Law, 24, p. 349, University of Utah S.J. Quinney College of Law, Salt Lake City, Utah.

Peck, J.C. and Nagel, D.K. (1989) Legal aspects of Kansas water resources planning, University of Kansas Law Review, 37(2), 199-318.

Pennsylvania v. West Virginia, 262 U.S. 553, 43 S.Ct. 658, 67 L.Ed. 1117 (1923).

Pike v. Bruce Church, Incorporated, 397 U.S. 137, 142, 90 S.Ct. 844, 847, 25 L.Ed.2d 174, 178 (1970).

Ponderosa Ridge LLC v. Banner County, 250 Neb. 944, 554 N.W.2d 151 (1996).

Potter, H.G., III, History and Evolution of the Rule of Capture (2004) 100 Years of Rule of Capture: From East to Groundwater Management, Texas Water Development Board, Report 361. Available at: http:// www.twdb.state.tx.us/publications/ reports/GroundWaterReports/GWReports/ Report $\% 20361 / 1 \% 20 \mathrm{CH} \% 20$ Potter.pdf.

Shah, T., Giordano, M., and Wang, J. (2004) Irrigation institutions in a dynamic economy: what is China doing differently from India?, Economic and Political Weekly. Available at: http://www.iwmi.cgiar.org/iwmi-tata/index. asp?id=1270.
Singh, K. (2002) Co-operative Property Rights as an Instrument of Managing Groundwater, World Water Council 3rd Word Water Forum, Kyoto, Japan.

Sipriano v. Great Springs Waters of America, Incorporated, 42 Tex.Sup.Ct.J. 629, 1 S.W.3d 75 (1999)

Sophocleous, M. (2005) Groundwater recharge and sustainability in the High Plains aquifer in Kansas, USA, Hydrology Journal, 13(2), 351-365.

South Dakota Codified Laws (2005) Available at: http://legis.state.sd.us/statutes/index.aspx. Spear T Ranch v. Knaub, 269 Neb. 177, 691 N.W.2d 116 (2005).

Sporhase v. Nebraska, 458 U.S. 941, 102 S.Ct. 3456, 73 L.Ed.2d 1254 (1982).

State of Kansas v. State of Nebraska and State of Colorado 2002 (No. 126, Original, U.S. Supreme Court) Special Master's First Report, p. 45, and Case Management Order 6 para. 3.

Testimony of David L. Pope, Chief Engineer, before the Senate Natural Resources Committee on the Republican River Compact Litigation, January 23, 2003. Available at: http://www.ksda.gov/Default. aspx?tabid=334\&mid=2356\&ctl=Downloa $\mathrm{d} \&$ method=attachment\&Entryld=229.

Texas Constitution (2005) Available at: http:// www.capitol.state.tx.us/txconst/toc.html.

Texas Water Code (2005) Available at: http:// www.capitol.state.tx.us/statutes/wa.toc.htm.

The Bimonthly Newsletter of the Oklahoma Water Resources Board (March-April 2001) Legislature Mulls First Interstate Groundwater Compact, Oklahoma Water Resources Board. Available at: http://www.owrb.state. ok.us/news/news2/pdf_news2/wnews/wn3_ 2001.pdf.

The Utton Center, Transboundary Resources (2004) The Model Interstate Surface and Groundwater Compacts Project, The University of New Mexico School of Law. Available at: http://uttoncenter.unm.edu/pdfs/MC_Project_ Description.pdf.

Thorson, N.W. (1991 and 2004 Cumulative Supplement) State Surveys, Nebraska, Waters and Water Rights, Vol. 6, The Michie Company, Charlottesville, Virginia. 
Water and the Future of Rural Texas (2001) Conference Proceedings, Texas Center for Policy Studies, Austin, Texas. Available at: http://www.texaswatermatters.org/pdfs/ articles/waterconf.pdf.

Water Ranching in the Lone Star State: Texas Water Policy Update (2002) Texas Center for Policy Studies. Available at: http://www. texaswatermatters.org/pdfs/txwaterpolicydec. pdf; http://www.texaswatermatters.org/pdfs/ tgxwaterpolicydec.pdf.
Waters and Water Rights (1991 and 2004 Cumulative Supplement) The Michie Company, Charlottesville, Virginia.

West v. Kansas Natural Gas Company, 221 U.S. 229, 31 S.Ct. 564, 55 L.Ed. 716 (1911).

Williams v. City of Wichita, 190 Kan. 317, 374 P.2d 578 (1962).

Wyoming Statutes (2005) Wyoming State Legislature, Wyoming Statutes. Available at: http://legisweb.state.wy.us/. 